\title{
Decreased Polyamine Content of Concanavalin A Stimulated Lymphocytes in Down's Syndrome Subjects
}

\author{
E. E. MCCOY, ${ }^{(19)}$ K. STRYNADKA, H. F. PABST, AND J. CRAWFORD \\ Department of Pediatrics, University of Alberta School of Medicine, Edmonton, Alberta, Canada T6G 263
}

\begin{abstract}
Summary
Increased polyamine content is associated with increased rates of cell growth. Several Down's syndrome (D.S.) tissues have been shown to have decreased growth rates. Studies were undertaken to determine if the polyamine content of stimulated D.S. lymphocytes was similar to that of stimulated normal cells. Lymphocytes were isolated and cultured in the presence of Concanavalin $A$ for 4 or 5 days. Polyamines were then extracted and quantitated. After 4 days spermidine content for normal cells was $930.9 \pm 127$ and for D.S. cells $489.2 \pm 113.1$ nmoles $/ 10^{9}$ cells $(P<0.025)$. Spermine content of normal cells was $1152.8 \pm 157.4$ and for D.S. cells $533.9 \pm 82.0(P<0.005)$. After 5 days in culture spermidine content of normal cells was $803.0 \pm 75.9$ and for D.S. cells $\mathbf{4 4 6 . 2}$ \pm 76.5 nmoles $/ 10^{9}$ cells $(P<0.005)$. Spermine content was 1155.7 \pm 121.9 for normal cells and $555.1 \pm 68.4$ nmoles $/ 10^{9}$ for $D . S$. cells. Decreased content of polyamines in D.S.-stimulated lymphocytes is most probably due to decreased rate of polyamine synthesis. Decreased content of polyamines in response to stimulation may be a factor in decreased growth rates and altered immune function seen in D.S. patients.
\end{abstract}

\section{Speculation}

Polyamine content is associated with increased rates of DNA and cell replication. If decreased polyamine synthesis occurred in multiple tissues in Down's syndrome, it could result in a total decrease in cell number and small stature present in Down's syndrome patients.

Several types of cells from subjects with Down's syndrome have been shown to have differences in growth characteristics and enzyme activities, compared to those from normal subjects. Down's syndrome fibroblasts have a lengthened doubling time (39 h) (14) and phytohemaglutinin-stimulated lymphocytes, decreased incorporation of $\left[{ }^{3} \mathrm{H}\right]$-thymidine into DNA (1). Down's syndrome patients usually have slower growth rates and are shorter in height than normal children. Their cells in culture have a decreased in vitro life span (16) compared to normal cells. The reason for short height and shortened in vitro life span is not known at present.

The polyamines, putrescine, spermidine and spermine, have been shown to have increased rates of synthesis or content in cells of tissue with increased rates of replication (13). Of the three polyamines, spermidine appears to be the important one in the enhancement of rates of DNA cell replication (15). To determine whether cells from D.S. subjects would synthesize polyamines at normal rates, polyamine content was determined in stimulated lymphocytes from normal and Down's syndrome subjects. The results show that stimulated Down's syndrome cells have significantly decreased content of polyamines compared to normal cells.

\section{MATERIALS AND METHODS}

Subjects. Written, informed consent was obtained from either parent or guardian of Down's syndrome subjects who lived at home and either attended a day school or worked in a sheltered workshop for the retarded. Ages ranged from 13-30 years. There was no apparent illness in these subjects. Control subjects were volunteer students, nursing ahd hospital personnel ages 18-30 years, who were in apparent good health.

Isolation of lymphocytes. Blood was collected in heparinized vacutainers. Lymphocytes were separated using the ficoll-hypaque technique (17). Separated mononuclear cells were counted using a hemocytometer, then diluted to a concentration of $1 \times 10^{6}$ cells/ $\mathrm{ml}$ in RPMI 1640 media (Gibco).

Culture technique. Eight tubes were set up for stimulated and unstimulated lymphocyte culture for each subject. Stimulated cultures were prepared similarly to controls except to each tube was added $80 \mu \mathrm{l}$ of a solution containing Concanavalin $\mathrm{A}$ (Con $\mathrm{A})$ at a concentration of $1 \mathrm{mg} / \mathrm{ml}$. Cultures of $2 \mathrm{ml}$ were prepared to contain $1 \times 10^{6}$ cells in RPMI 1640 media containing autologous plasma of $15 \% \mathrm{v} / \mathrm{v}$ final concentration.

Extraction and quantitation of polyamines. On the fourth or fifth day, the cultures were aspirated down to a volume of $0.2 \mathrm{ml}$, care being taken not to disturb the cell button. One $\mathrm{ml}$ of $5 \%$ sulfosalicylic acid was added to each tube. Culture tubes were chilled in ice and cells disrupted using the microtip of a Bronson sonifier at $60 \mathrm{amp}$ setting for $5 \mathrm{sec}$ intervals for five times. The control or Con A treated tubes were then combined and kept in ice for $1 \mathrm{~h}$. Tubes were centrifuged at $15,000 \mathrm{rpm}(27,000 \times \mathrm{g})$ for $30 \mathrm{~min}$ at $4^{\circ} \mathrm{C}$ in a Sorval RC2-B centrifuge. The supernatants were separated and frozen at $-70^{\circ} \mathrm{C}$ until used. The supernatants were lyophilized and a volume of $0.1-0.2 \mathrm{ml}$ of $0.1 \mathrm{~N} \mathrm{HCl}$ was added to each sample. The sample was aspirated from the tube and it plus two $0.1 \mathrm{ml}$ rinses of $0.1 \mathrm{~N} \mathrm{HCl}$ was applied to a PA-35 resin column of a Beckman $120 \mathrm{C}$ amino acid analyzer. Polyamines were eluted using a citrate buffer system and the amount of each polyamine calculated using a Beckman AA computing integrator. At the start of each day a standard mixture of polyamines was quantitated and used by the computing integrator for comparison of subsequent unknown sample runs for that day. Results for individual experiments are presented as nmoles of spermidine or spermine $/ 10^{9}$ original cells and the results of a group expressed as the average \pm S.E. Statistical significance for differences was determined using the unpaired $t$ test.

\section{RESULTS}

Polyamine content of nonstimulated lymphocytes. Negligible amounts of putrescine were present in both control and Down's syndrome (D.S.) cells suggesting further transformation of this compound. The content of both spermidine and spermine in 4day- and 5-day-cultured lymphocytes was not significantly different in control compared to D.S. cells $(P>0.05)$ (see Tables $1-4)$. 
Table 1. Spermidine content of 4-day Concanavalin A-stimulated lymphocytes, control and Down's syndrome $\left(\right.$ nmoles $/ 10^{-9}$ original cells) ${ }^{l}$

\begin{tabular}{|c|c|c|c|c|c|c|}
\hline $\begin{array}{c}\text { Experi- } \\
\text { ment }\end{array}$ & \multicolumn{3}{|c|}{ Control (normals) } & \multicolumn{3}{|c|}{ Down's syndrome } \\
\hline 1 & 148.75 & 636.25 & $487 . a 50$ & 60.00 & 230.00 & 170.00 \\
\hline 3 & 68.80 & 1395.00 & 1326.20 & 27.50 & 426.30 & 398.80 \\
\hline 4 & 58.80 & 677.50 & 618.70 & 23.80 & 385.00 & 361.20 \\
\hline 5 & 157.50 & 851.30 & 693.80 & 132.50 & 977.50 & 845.00 \\
\hline \multirow[t]{2}{*}{8} & & & 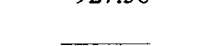 & 116.00 & 533.30 & 417.30 \\
\hline & $116.45 \pm 35.80^{2}$ & $930.90 \pm 127.43^{3}$ & $814.49 \pm 115.54$ & $78 . \overline{42 \pm 16.54}$ & $489.23 \pm 113.11^{3,4}$ & $410.80 \pm 102.94^{5}$ \\
\hline
\end{tabular}

${ }^{1}$ Spermidine content of nonCon A- and Con A-stimulated lymphocytes was determined by ion exchange chromatography as outlined in "Methods." NonCon A cells were grown in media without added Con A whereas Con A cells had $40 \mu \mathrm{g} / \mathrm{ml}$ Con A added to the media.

${ }^{2}$ Mean \pm S.E.

${ }^{3}$ Increase in spermidine content in Con A compared to nonCon A stimulated cells (controls and Down's syndrome); $P<0.001$.

${ }^{4}$ Comparison of increase in spermidine in Con A stimulated control and Down's syndrome cells; $P<0.025$.

${ }^{5}$ Comparison of net increase in spermidine content in Con A stimulated normal and Down's syndrome cells; $P<0.025$.

Table 2. Spermine content of 4-day Concanavalin A-stimulated lymphocytes, control and Down's syndrome $\left(\mathrm{nmoles} / 10^{-9}\right.$ original cells) ${ }^{l}$

\begin{tabular}{|c|c|c|c|c|c|c|}
\hline \multirow{2}{*}{$\begin{array}{c}\text { Experi- } \\
\text { ment }\end{array}$} & \multicolumn{3}{|c|}{ Control (normals) } & \multicolumn{3}{|c|}{ Down's syndrome } \\
\hline & NonCon A & Con A & Net increase & NonCon A & Con $\mathrm{A}$ & Net increase \\
\hline 1 & 368.75 & 850.00 & 481.25 & 217.50 & 311.25 & 93.75 \\
\hline 2 & 307.50 & 1583.80 & 1276.30 & 251.25 & 752.50 & 501.25 \\
\hline 3 & 318.80 & 1848.80 & 1530.00 & 161.30 & 400.00 & 238.70 \\
\hline 4 & 178.80 & 847.50 & 668.70 & 110.00 & 521.30 & 411.30 \\
\hline 5 & 491.30 & 1160.00 & 668.70 & 252.50 & 932.50 & 680.00 \\
\hline 6 & 210.00 & 735.00 & 525.00 & 297.50 & 471.30 & 173.80 \\
\hline 7 & 182.50 & 1045.00 & 862.50 & 130.70 & 239.40 & 108.70 \\
\hline \multirow[t]{2}{*}{8} & & & - & $\underline{215.00}$ & $\underline{643.30}$ & $\underline{428.30}$ \\
\hline & $293.75 \pm 43.11^{2}$ & $1152.87 \pm 157.45^{3}$ & $858.92 \pm 150.48$ & $204 . \overline{46 \pm 23.01}$ & $533.94 \pm 82.04^{3,4}$ & $329.47 \pm 73.87^{5}$ \\
\hline
\end{tabular}

${ }^{1}$ Spermine content of nonCon A- and Con A-stimulated lymphocytes was determined by ion exchange chromatography as outlined in "Methods."

${ }^{2}$ Mean \pm S.E.

${ }^{3}$ Increase in spermine content of control and Down's syndrome Con A-stimulated cells compared to nonCon A-stimulated cells; $P<0.001$.

${ }^{4}$ Comparison of spermine content in Down's syndrome and control Con A-stimulated cells; $P<0.005$.

${ }^{5}$ Comparison of net increase in spermine content of Con A-stimulated normal compared to Down's syndrome cells; $P<0.01$.

Table 3. Spermidine content $f$ 5-day Concanavalin A-stimulated lymphocytes, control and Down's syndrome $\left(\mathrm{nmoles}^{\prime} / 0^{-9}\right.$ original cells) $^{I}$

\begin{tabular}{|c|c|c|c|c|c|c|}
\hline $\begin{array}{c}\text { Experi- } \\
\text { ment }\end{array}$ & \multicolumn{3}{|c|}{ Control (normals) } & \multicolumn{3}{|c|}{ Down's syndrome } \\
\hline 1 & 121.25 & 690.00 & 568.75 & 80.00 & 347.50 & 267.50 \\
\hline 3 & 105.00 & 580.00 & 475.00 & 38.80 & 208.80 & 170.00 \\
\hline 4 & 97.50 & 981.30 & 883.80 & 28.00 & 426.30 & 398.30 \\
\hline 5 & 70.00 & 583.80 & 513.80 & 108.85 & 667.50 & 558.75 \\
\hline 8 & 101.25 & 800.00 & 698.75 & 78.30 & 643.30 & 565.00 \\
\hline \multirow{2}{*}{-} & 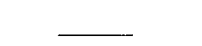 & $\ldots$ & $\ldots$ & 52.50 & $\underline{585.00}$ & $\underline{532.50}$ \\
\hline & $102 . \overline{46 \pm 20.01^{2}}$ & $803 . \overline{30 \pm 75.91^{3}}$ & $700.83 \pm 77.80$ & $67.03 \pm 13.29$ & $446.27 \pm 76.55^{3,4}$ & $379.23 \pm 67.15^{5}$ \\
\hline
\end{tabular}

\footnotetext{
${ }^{1}$ Quantitation of lymphocyte spermidine content as outlined in Table 1.

${ }^{2}$ Mean \pm S.E.

${ }^{3}$ Increase in spermidine content in Con A- compared to nonCon A-stimulated cells (controls and Down's syndrome); $P<0.001$.

${ }^{4}$ Comparison of increase in spermidine in Con A-stimulated control and Down's syndrome cells; $P<0.005$.

${ }^{5}$ Comparison of net increase in spermidine content in Con A-stimulated normal and Down's syndrome cells; $P<0.01$.
} 
Table 4. Spermine content of 5-day Concanavalin A stimulated lymphocytes, control and Down's syndrome (nmoles $/ 10^{-9}$ original cells) ${ }^{\prime}$

\begin{tabular}{|c|c|c|c|c|c|c|}
\hline $\begin{array}{c}\text { Experi- } \\
\text { ment }\end{array}$ & \multicolumn{3}{|c|}{ Control (normals) } & \multicolumn{3}{|c|}{ Down's syndrome } \\
\hline 1 & 610.00 & 956.25 & 346.25 & 247.50 & 382.50 & 135.00 \\
\hline 3 & 367.50 & 928.80 & 561.30 & 155.00 & 347.50 & 192.50 \\
\hline 4 & 401.30 & 1725.00 & 1323.70 & 153.80 & 521.30 & 367.50 \\
\hline 5 & 133.80 & 790.00 & 656.20 & 242.50 & 810.00 & 567.50 \\
\hline 8 & 107.50 & 1100.00 & 992.50 & 165.00 & 683.30 & 518.30 \\
\hline \multirow[t]{2}{*}{9} & & & - & 80.00 & $\underline{673.80}$ & $\underline{593.80}$ \\
\hline & $330 . \overline{48 \pm 57.50^{2}}$ & $1155 . \overline{79 \pm 12} 1.95^{3}$ & $825 . \overline{30 \pm 131.5}$ & $182 . \overline{78 \pm 18.38}$ & $555.1 \overline{7 \pm 68.43^{3,4}}$ & $372.38 \pm 68.54^{5}$ \\
\hline
\end{tabular}

'Quantitation of lymphocyte spermine content as in Table 2.

${ }^{2}$ Mean \pm S.E.

${ }^{3}$ Increase in spermine content of control and Down's syndrome Con A-stimulated cells compared to nonCon A-stimulated cells; $P<0.001$.

${ }^{4}$ Comparison of spermine content in Down's syndrome and control Con A-stimulated cells; $P<0.001$.

"Comparison of net increase in spermine content of Con A-stimulated normal compared to Down's syndrome cells; $P<0.01$.

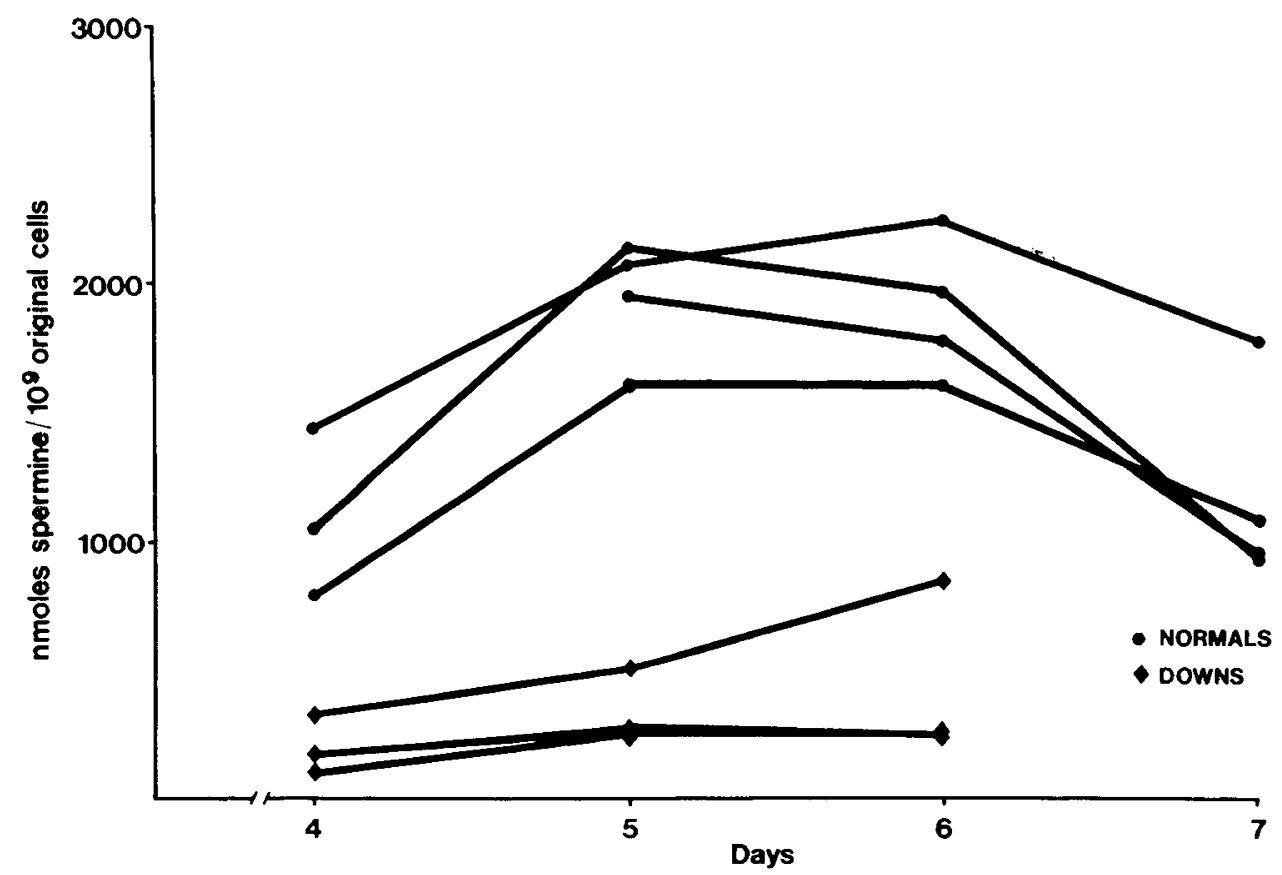

Fig. 1. Lymphocytes from normal and Down's syndrome subjects were cultured in presence of Concanavalin A. Cells were harvested at days shown and spermidine quantitated as described in "Methods and Materials." Results are expressed as nmoles spermidine $/ 10^{9}$ original cells.

Spermidine and spermine content of a 4-day-cultured concanavalin $A$ stimulated lymphocytes. The average content of spermidine in lymphocytes cultured for 4 days in the presence of Con $A$ was $930.0 \pm 127.4$ nmoles $/ 10^{9}$ normal cells compared to $489.2 \pm 113.1$ nmoles $/ 10^{9}$ D.S. cells $(P<0.001)$. The net increase of spermidine in normal lymphocytes was $814.4 \pm 115.5$ nmoles $/ 10^{9}$ cells compared to $410.8 \pm 102.9$ nmoles $/ 10^{9}$ D.S. cells $(P<0.025)$.

The average content of spermine in 4-day-cultured lymphocytes with added Con $A$ was $1152.8 \pm 157.4$ nmoles $/ 10^{9}$ normal cells and $533.9 \pm 82.0$ nmoles $/ 10^{9}$ D.S. cells $(P<0.005)$. Net increase in spermine content of normal lymphocytes was $858.9 \pm 150.4$ nmoles $/ 10^{9}$ cells while for D.S. the net increase was $329.4 \pm 73.8$ nmoles $/ 10^{9}$ cells $(P<0.01)$.

Spermidine and spermine content of lymphocytes cultured 5 days in the presence of concanavalin $A$. Spermidine and spermine content were determined on day 5 to determine that the difference in polyamine content observed on day 4 was sustained and not a time dependent observation.

The average content of spermidine in normal lymphocytes cultured 5 days in the presence of Con $A$ was $803.3 \pm 75.9$ nmoles/
$10^{9}$ cells. This was less than was present on day 4. D.S. cells had a spermidine content of $446.2 \pm 76.5$ nmoles $/ 10^{9}$ cells which was slightly less than on day 4 . The net increase of spermidine was $700.8 \pm 77.8$ nmoles $/ 10^{9}$ normal cells whereas for D.S. cells the increase was $379.2 \pm 67.1$ nmoles $/ 10^{9}$ cells. Both the content and net increase in spermidine was significantly less in D.S. cells (Table 3).

The spermine content of 5 day Con A-stimulated lymphocytes from controls was $1155.7 \pm 121.9 \mathrm{nmoles} / 10^{9}$ cells while for D.S. subjects it was $555.1 \pm 68.4$ nmoles $/ 10^{9}(P<0.001)$. These values are essentially the same as those on day 4 for both D.S. and normal cells. The net increase in spermine content was $825.3 \pm$ 131.5 nmoles $/ 10^{9}$ for control and $372.3 \pm 68.5$ nmoles $/ 10^{9}$ cells in D.S. The net increase was similar to that seen in 4-day-stimulated cells.Polyamine content of media from control and Down's syndrome lymphocytes. The media which consisted of RPMI 1640 and autologous serum was analyzed for polyamine content after 4 and 5 days in culture. This was done to determine if the decreased polyamine content in D.S. cells was due to increased outward leak or transport. Neither spermidine nor spermine could be demon- 
strated in control or D.S. media. As human serum is reported to not contain a monamine oxidase (2) for spermidine or spermine, the results were interpreted to indicate D.S. cells do not leak polyamines at an increased rate into media.

Polyamine content of concanavalin A-stimulated lymphocytes from day 2 to day 7 in culture. Normal and D.S. lymphocytes were cultured and harvested from day 2-7 to determine if differences in the peak period of polyamine content occurred in D.S. cells. The results showed (Fig. 1) that both D.S. and normal cells had significant increases in polyamine content starting on day 3 in culture and peaked between day 5 or 6 . The decrease in polyamine content in D.S. cells cannot be ascribed to differences in time of maximum content of these cells.

\section{DISCUSSION}

Polyamines have been postulated to play a role in regulation of growth but the manner in which this is carried out is not clear (15). Increased rates of polyamine synthesis as an early event in embryonic development (12), regeneration of liver following partial hepatectomy (13), cardiac hypertrophy (4) and neoplastic cell growth (11) have been noted. In the absence of spermidine, a decreased rate of DNA synthesis occurs (7). Increased polyamine synthesis has been associated with increased RNA synthesis (5) and ornithine decarboxylase has been postulated to be an initiation factor for RNA polymerase (8). We postulate that decreased fibroblast growth rate (14), decreased DNA polymerase activity (1) and decreased uptake of $\left[{ }^{3} \mathrm{H}\right]$-thymidine in D.S. lymphocytes (10) may be associated with decreased rates of polyamine synthesis.

Conacanavalin A stimulates human $\mathrm{T}$ lymphocytes to high rates of metabolic activity. Morris (9) has shown in Con A stimulated bovine lymphocytes, polyamine accumulation occurs by $8 \mathrm{~h}$, DNA synthesis at $24 \mathrm{~h}$, and replication at $30 \mathrm{~h}$. Inhibitors of polyamine synthesis reduced DNA synthesis by $50-75 \%$. Although we have not measured DNA polymerase activity of $\left[{ }^{3} \mathrm{H}\right]$-thymidine uptake in the present experiments, the decreased polyamine content of D.S.-stimulated lymphocytes is compatible with the previous noted differences in D.S. lymphocytes.

The results show that at both day 4 and day 5 of Con $A$ stimulation, the content of spermidine and spermine was decreased in D.S. lymphocytes. The net increase in content of both polyamines. was also less in D.S. cells.

The time course of polyamine accumulation in Con A-stimulated lymphocytes was studied to determine whether the pattern was similar in D.S. and control cells. The results showed that the increase in polyamine content began in both D.S. and control cells on day 3, peaked on day 5-6 and began to decrease by day 7 . These results exclude a delay in polyamine accumulation as a cause for decreased content in D.S. lymphocytes. We have also shown that increased leakage of polyamines from D.S. cells does not occur. At present we propose that a decreased rate of synthesis or increased rate of degradation of polyamines account for decreased polyamine content in Con A-stimulated lymphocytes in D.S. If a decreased rate of synthesis of polyamines is present in D.S. lymphocytes, one or more points on the synthetic pathway may be involved. Examples of possible areas of involvement include decreased uptake of ornithine into D.S. cells, decreased activity of or increased rate of degradation of ornithine decarboxylase and decreased S-adenosylmethionine decarboxylase activity.
In addition to a possible relationship to the small stature of Down's syndrome subjects, these observations may relate to the altered immune status of these patients. Levin et al. (6) has attempted to correlate the increased incidence of infections in D.S. patients with decreased $T$ cell function. He states that D.S. have diminished numbers of $\mathrm{T}$ cells and a functional deficiency exists in these cells. Whittingham et al. (18) found an increased number of $T$ lymphocytes in D.S. but these cells also had impaired function.

The results are of interest in relation to the hypothesis proposed by Dwyer (3) that polyamines may play a role in regulation of the immune response at the step of lymphocyte activation. Decreased polyamine content of D.S. lymphocytes may be linked to a decreased rate of $\mathrm{T}$ cell transformation or alternately, decreased polyamine content could reflect a decreased number of $T$ cells present. Further work will clarify these possibilities.

\section{REFERENCES AND NOTES}

1. Agarwal, S. S., Blumberg, B. S., Gerstly, B. J., London, W. T., Stunick, A. I., and Loeb, L. A.: DNA polymerase as an index of lymphocyte stimulation: studies in Down's syndrome. J. Clin. Invest., 49: 161 (1970).

2. Bachrach, U.: Function of naturally occurring polyamines. p 57 Academic Press, NY (1973).

3. Dwyer, D.S.: Regulation of the immune response by polyamines. Medical Hypothesis, 5: 1169 (1979)

4. Feldman, M. J. and Russell, D. H.: Polyamine biogenesis in left ventricle of the rat heart after constriction. Am. Jour. Physiol, 222: 1199 (1972).

5. Fillingame, R. H. and Morris, D. R.: Polyamine accumulating during lymphocyte transformation and its relation to the synthesis, processing and accumulation of ribonucleic acid. Biochem., 12: 4479 (1973).

6. Levin, S. L., Schlesinger, M., Handzel, Z., Hahn, T., Attman, Y., Czernobilsky, B., and Boss, J.: Thymic deficiency in Down's syndrome. Pediatrics, 63: 80 (1979).

7. Mamont, P. S., Böhlen, P., McCann, P. P., Bey, P., Schuber, F., and Tardif, C.: $\alpha$-Methyl ornithine, a potent competitive inhibitor of ornithine decarboxylase, blocks proliferation of rat hepatoma cells in culture. Proc. Nat. Acad. Sci. (USA), 73: 1626 (1976).

8. Manen, C.-A. and Russeil, D. H.; Ornithine decarboxylase may function as an initiation factor for RNA polymerase I. Science, 195: 505 (1977).

9. Morris, D. R.: Polyamine formation in rapidly proliferating cells. In: Advances in Polyamine Research, Vol. 1, Ed.; R. A. Campbell et al., p. 105 (Raven Press, New York, NY 1978)

10. Rigas, D. A., Elsasser, P., and Hecht, F.: Impaired in vitro response to circulating lymphocytes to phytohemaglutinin in Down's syndrome: dose and time-response curves and relation to cellular immunity. Int. Arch. Allergy Appl. Immunol., 39: 587 (1970).

11. Russell, D. H. and Levy, C. C.: Polyamine accumulation and biosynthesis in mouse L1210 leukemia. Cancer Research, 31: 248 (1971).

12. Russell, D. H. and McVicker, T. A.: Polyamines in developing rat and in supportive tissues. Biochem. Biophys. Acta, 259: 247 (1972).

13. Russell, D. and Snyder, S. H.: Amine synthesis in rapidly growing tissues: ornithine decarboxylase activity in regeneration rat liver, chick embryo, and various tumors. Proc. Nat. Acad. Sci., 60: 1420 (1968).

14. Segal, D. J. and McCoy, E. E.: Studies on Down's syndrome in tissue culture. I. Growth rates and protein contents of fibroblast cultures. J. Cell. Physiol., 83: 85 (1974).

15. Shields, R.: Polyamines and growth control. Nature, 261: 455 (1976)

16. Schneider, E. L. and Epstein, C. J.: Replication rate and lifespan of cultured fibroblasts in Down's syndrome. Proc. Soc. Exp. Biol. Med., 141: 1092 (1972).

17. Thorsby, E. and Bratlie, A.: A rapid method for preparation of pure lymphocyte suspension. In: Histocompatibility Testing, p. 655. P. Terasaki, Ed. (Munksgaard, Copenhagen, 1970).

18. Whittingham, S., Sharma, D. L. B., Pitt, D. B., and MacKay, I. R.: Stress deficiency of the T-lymphocyte system exemplified by Down's syndrome. Lancet, 1 : 163 (1977).

19. Requests for reprints should be addressed to: Dr. E. McCoy, Department of Pediatrics, Clinical Sciences Building. University of Alberta, Edmonton, Al berta, Canada T6G 2G3.

20. Received for publication September 25,1978

21. Accepted for publication August 20, 1981. 